\title{
Awareness of Teaching through Action Research: Examples, Benefits, Limitations
}

\author{
Jerry G. Gebhard \\ Indiana University of Pennsylvania
}

In this article I describe three action research projects conducted by teachers at Teachers College, Columbia University, Tokyo MA TESOL Program. I discuss the benefits of doing action research (how it helps us to make more informed teaching decisions; gain skills at posing and solving teaching problems; expand reflective skills; create a forum to discuss teaching issues and beliefs), as well as its limitations (a focus only on problems; a narrowly defined linear process). I then highlight other avenues to expand awareness, such as "exploring to see what happens" by trying the opposite, exploring "what we actually do" as opposed to "what we think we do," considering "what we believe in relation to what we do," and exploring to "gain emotional clarity."

本論文はコロンビア大学ティーチャーズ・カレッジ東京校における英語教授法修士課程 プログラムに学ぶ英語教員が行った 3 種のアクション・リサーチ・プロジェクトの報告で ある。調査の結果、情報に基づいた判断を行う能力が養成できること、自ら問題を設定し それを解決する技能が身につくこと、自らの指導を客観的に振り返る能力が要請できるこ と、指導について討論する場が得られることなどが利点であることがわかった。改善すべ き点としては、問題点に関心が集中してしまう傾向があること、扱う範囲が狭められ多面 的な視点が失われがちであることなどである。これらの結果に基づいて、わざと自分のビ リーフと違うことをやってどのような結果になるかを見る、何をしていると思うかではな く実際に何をしているのかを考察してみる、自分の指導に照らし合わせて自らの教育理念 を探ってみる、自らの理念をはっきりとさせてみる、など新たなアクション・リサーチの 方法を提示した。

here are a variety of activities teachers can use to develop their teaching beliefs and practices. For example, Bailey, Curtis, and

1 Nunan (2001), Gebhard (1992, in press), Gebhard and Oprandy (1999), and Richards and Farrell (2005), discuss how teachers can develop their teaching through the use of case studies, peer observation,

JALT Journal, Vol. 27, No. 1, May, 2005 
self-observation with video, team-teaching, mentoring, coaching, teaching portfolios, learning a second language, talking with supervisors, teaching journals, and action research. This article focuses on one of these teacher development activities-action research.

At the most basic level, action research is a problem-posing cyclic process, through which teachers can identify, investigate, and try to solve problems in their teaching. The cyclic process begins with a search for a teaching problem, often based on intuition and informal observations. A next step is to learn more about the problem. For example, the teacher might videotape classroom interaction or ask students to complete a short questionnaire. After investigating the problem, the teacher can reflect on what has been learned, as well as guess what might happen if changes are implemented. Next, the teacher plans changes that aim at solving the problem, then implements the plan, observes what happens, reflects on the consequences, plans the next actions, and continues the cycle.

However, as Crookes (1993) and van Lier (1993) point out, action research is more than this. Rather than just trying to solve classroom problems, teachers can work through a process of problem posing to explore aspects of teaching not only within the classroom, but also in the school and larger community that might affect what happens in the classroom. In addition, as Burns (1996) and Crookes (1993) point out, the cyclic process is enhanced when teachers have chances for collaboration with others, such as colleagues, administrators, and parents, as they work through the process.

Those who have published their action research projects on EFL or ESL teaching (for example, Cornwell, 2001; Curtis, 2001; Sitler \& Tezel, 1999; Stewart, 2001; Thorne \& Wang, 1996) or focus attention on the process and benefits of doing action research (Burns, 1996, 1997; Burns \& Hood, 1997, Farrell, 2001; Gebhard, 1999; Kemmis \& McTaggart, 1982; Wallace, 1998) all directly or indirectly indicate the following: By using action research, we can gain skill at posing problems in our teaching, as well as work at solving the problems, and this process can make us more aware of our teaching. Likewise, action research can expand our reflective skills and provide a forum through which we can discuss teaching issues, pose problems, and address teaching beliefs and practices.

However, as I shall bring to light in more detail, action research focuses noticeably on problems in our teaching and uses a rather narrowly defined linear process, and this may limit the kind of awareness we can generate from just doing action research. As such, in addition to doing 
action research, I encourage teachers to look beyond the problem-posing process of action research, and make use of other avenues to teaching awareness.

With this introductory statement in mind, I shall (a) describe three action research projects done by teachers enrolled in the Teachers College, Columbia University, Tokyo MA TESOL program, (b) discuss the benefits of using action research, and (c) highlight how action research possibly places limitations on our awareness, as well as show how we, as teachers, can go beyond action research by exploring different avenues to expand our awareness.

\section{Action Research: Three Teachers' Problem-Posing Processes The Context of the Action Research Projects}

Teachers studying in a course titled Observation, offered in the Teachers College MA TESOL program in Tokyo, did the three action research projects described. The MA TESOL program accepts mostly experienced teachers who will continue teaching while also taking its courses. The idea is for them to use their teaching settings as places where they can apply what they are learning in the program, and this idea is a central part of the Observation course.

In the Observation course seminar the teachers read and talk about the cyclic process of doing action research, including how to identify and pose problems, do a preliminary investigation, reflect, plan an action, implement the plan, observe the outcome, reflect again, and plan the next action. We also discuss the social implications of action research, such as how the cyclic problem-posing process can reach beyond the classroom and into the school and larger community, as well as the need to collaborate with others while doing action research. In this regard, students in the observation course form collaborative-support groups. With the backing of fellow-members of the support group, each teacher is asked to work through the cyclic action research process, using his or her own teaching setting as the context for the project.

Teachers in the Observation course have generated a number of action research projects, as the partial list of topics given below shows. To further illustrate the action research projects, following this list I provide descriptions of three of the teachers' projects. Keep in mind that I do not consider any one project to be more valuable than another; each was selected simply to illustrate different teaching settings and uses of action research with them. 


\section{Example Action Research Topics}

- Getting students to speak

- Increasing students' fluency

- Making instruction in English more comprehensible

- Getting students to read for meaning

- Decreasing teacher talk and increasing student talk

- Making grammar rules comprehensible to students
- Lowering student anxiety

- Using praise to motivate students

- Motivating students to read English for pleasure

- Improving students' comprehension of the teacher's questions in English

- Changing disruptive students' behavior

- Decreasing the amount of spoken Japanese in the classroom

\section{An Action Research Project: How Can I Get Students to Get the Main Idea?}

Sachiko Kimura ${ }^{1}$ teaches English at a high school where there is a lot of emphasis on preparing students to pass university entrance exams. The emphasis is mostly on reading and grammar, and the school administration asks teachers to use Grammar-Translation methodology in their teaching. Through her use of Grammar-Translation, Sachiko believed that many of the students had trouble comprehending her lessons. For example, she observed that most of the students could not tell her, even in Japanese, the main idea of the reading passage she had just translated for them.

Through consultation with her Teachers College collaborative-support group, Sachiko decided to learn more about the students and interaction in the classroom, and she did this in three ways. First, she audio-taped the class and studied the interaction; second, she had the students complete a questionnaire; third, she kept a reflective journal on what went on during the lessons. By listening to the audio tape and writing in her reflective journal, she further realized that she lectured a lot in Japanese and followed a common teacher-solicit, student-response, teacher-react way of teaching (Bellack, Kliebard, Hyman, \& Smith, 1966; Fanselow, 1977). She additionally realized that most of the time was spent going over the meaning of words and that her questions to students were 
often about vocabulary. She also realized that some students had trouble paying attention. Many looked bored; a few even fell asleep.

She also learned something about the students' perceptions about the class from their responses to her questionnaire. All the students "got relief from translation"; most said they think about the content when they read, but they cannot fully comprehend the meaning.

Based on discoveries from her explorations, Sachiko set two specific goals: (a) to teach students how to identify the main idea of reading passages, and (b) to make her reading lessons interesting to the students. Instead of lecturing in Japanese, she decided to talk less, have students study a handout that explained the structure of a paragraph, including how to locate the main idea, and to write down answers to questions about the meaning in each paragraph. When she implemented the lesson, she again taped the class and reflected on it in her journal. She also asked students to complete another short questionnaire.

She recognized that she spoke much less, as planned, and that students were no longer sleeping. In addition, some students asked her questions to check their understanding of the reading. All in all, the class was much more attentive. Students said they liked doing the handout activity more than listening to her translation and grammar explanations. However, Sachiko also discovered that many of the students still could not identify the main idea in a passage.

Sachiko thought about how to solve the comprehension problem, and after discussing it with her classmates at Teachers College, she decided to continue to use handouts and have students complete worksheets, as well as write summaries of the paragraphs in both English and Japanese. She would also encourage students to ask questions, as she believed that when students inquire about meaning, they are learning. This rarely happened when she lectured, translated, and asked questions.

\section{A Second Action Research Project: The Use of Japanese and English}

At the time of this action research project Ikuko Matsumoto was teaching English in a junior high school in Yokohama. After talking with her support group at Teachers College, she felt that she was using too much Japanese in her teaching, and as a starting point to improve students' speaking abilities, she decided that she wanted to use more English with her students.

To learn more about her use of Japanese and English, Ikuko decided to videotape classroom interaction. She showed the tape to her Teachers College support group, and together they studied the interaction on the 
tape to see when she and the students used Japanese and English. They found that Japanese was used $75 \%$ of the time. Ikuko used Japanese to give instructions, explain points of grammar, vocabulary items, and homework assignments, as well as to translate passages and to discipline students. The students used Japanese to answer the teacher's questions and to ask the teacher questions. The teacher used English to greet, to praise, and to read passages and ask questions from the text. The students used English to greet the teacher, read from the text and to answer questions about the content of the text, such as giving a quote from an author.

Ikuko felt personally surprised and bothered by how much Japanese she used, as this conflicted with her belief that her job was partly to provide chances for students to experience the use of English to communicate their thoughts and feelings. She knew that many of the students would not feel comfortable speaking English with her because they all share Japanese as their first language. She also felt that some students would not be able to comprehend her use of English, for instance, to give grammar explanations and instructions, as they were accustomed to hearing these in Japanese. However, she believed that given enough time and success with comprehending her English, the students' communicative abilities would improve.

After collaborating with her support group about possible ways to bring English into the class, Ikuko planned to make two small changes in her use of English in the classroom. First, she decided to give classroom activity instructions in English. Second, she decided to ask students questions that are based on the content of the readings, but not those in the textbook, which students could simply read. For example, she would ask, "We read about food in England. If you went to England, what would you like to eat?"

As Ikuko taught the lesson, she used a small digital camcorder to record the class, focusing the camera on the students so she could capture their reactions to her instructions and questions. After the class she viewed the recording, made short transcriptions and analyzed the English used in her instructions. She also studied how the students reacted to these English language instructions, including their nonverbal reactions, such as their facial expressions and gestures. She also made short transcriptions and analyzed the interaction when she asked students questions in English.

Ikuko discovered that the majority of the students looked as if they were following the instructions, but most could not start the task (to silently read a passage in their text, answer six questions, as well as write 
down one question of their own) without first confirming this in Japanese. She also discovered that when she asked questions in English that were not in the text, most students, as she predicted, avoided eye contact with her and did not volunteer to answer. However, there were also surprises. It took much more time than she had anticipated for the question-answer session. She was also surprised that two students who were usually quiet volunteered to answer questions and did so in fairly fluent English.

Ikuko was also able to see that the number of students (40), the room itself, and the way students were sitting (in rows) limited the kind of question-answer communication she was hoping to have with them. She noticed, for example, that she stood in the front of the room and most interaction took place with students sitting in the front left side of the room.

Ikuko reflected on what happened. She believed that she became much more aware of how much Japanese is actually used in her English classes; she also felt a stronger commitment to using more English. Also, she realized that giving instructions and asking a few questions (not in the text) in English was only the beginning. She knew that she would have to take the students gradually through a process of switching from Japanese to using English, and that this would not be easy. One main reason for this, she thought, was because of the limitations placed on her and the students due to traditional beliefs within the exam-oriented Japanese educational system. As Ikuko explained: "Teachers and students, and even parents, believe that to improve English, students should analyze complex grammar rules and be good translators...[This is] because these skills are useful to pass exams."

In this regard, Ikuko felt discouraged about the prospect of successfully getting students to use English as the language of communication in the class. However, she decided to continue to try. She next planned to write key words from her instructions on the board and to point to these words as she gives activity instructions orally in English. She also planned to give students time to write down answers to her questions before asking them to answer them orally.

\section{A Third Action Research Project: Adult Learners' Interaction and Autonomy}

When Shelly Jordon was working on this action research project, she was teaching English to adults at a private language school, and she was especially interested in improving her teaching in her Travel English 
course. Her class included ten students between the ages of 40 and 60 . These students planned to travel abroad and needed to gain competence in listening to and speaking in English when traveling.

Shelly sensed that she was talking much more than the students. After talking with her Teachers College support group members, she was able to ask questions like, "How much do I talk? How much do the students talk to me? How much do they talk to other students? When do they talk in a natural direct way without my encouragement? Do the students actively listen to each other?"

Shelly videotaped classroom interaction during pair work activities and whole-class discussion. She then met with her support group, and together they transcribed (including nonverbal behaviors) and analyzed random sections of the pair work and whole-class discussions. Shelly discovered that during pair work, the students talked $70 \%$ and she $30 \%$. Further, through her analysis of nonverbal behaviors, she saw that the students were not displaying "natural" animated interaction when they talked to each other. For example, one student wrote throughout the entire session, seldom looking at the teacher or other students. Another student kept looking at the teacher while her classmate was talking. Shelly also discovered that during whole-class discussions, she spoke $46 \%$ of the time and students $54 \%$. However, although it seemed like the students were talking more, Shelly pointed out that students often took a long time to express an idea, including some rather long pauses. When Shelly spoke to students during the whole class discussion and pair work activity, the interaction followed a traditional teacher-solicit, student-response, and teacher-react pattern.

Shelly wanted to decrease the amount of talking she did and increase student-talk, as well as provide an atmosphere for students to have natural animated discussions in English. To do this she decided to rearrange the seats so that pairs could easily see each other. She also decided to stand where she was not the center of attention and to limit her English to giving verbal instructions. As a result, the students spoke close to $100 \%$ during the pair work activities, maintained consistent eye contact with each other, and used a variety of gestures, body language and facial expressions while speaking. For example, they pointed to themselves and used their hands to indicate size or an action.

Shelly said she learned how to be less dominant in the class simply by not talking, arranging chairs so students could see each other, and by standing outside "center stage." By doing these things, students seemed to have more animated natural conversations with each other in English, 
although they did use Japanese at times. She decided to continue the cycle of action research by having students complete a questionnaire about the kinds of activities they would like to do in the class, then implement these activities to see what happens. She also decided "to dig deeper into the analysis of transcripts" and to identify patterns in the way she and the students interact with each other while doing these activities.

\section{Benefits of Action Research More Awareness of Our Teaching}

There are at least three benefits to doing action research. To begin, continuous posing of problems and cycling and recycling of behavioral changes to better understand our teaching can provide much more awareness of the consequences that our teaching has on interaction in the classroom. For example, Sachiko realized students could not summarize the meaning of the reading selection even in Japanese after she had explained it. Ikuko found that most of the students did not have confidence in their abilities to understand her English instructions as most could not start the reading activity without first asking her to explain the task in Japanese. Shelly became aware that by changing seating arrangements and repositioning herself to a less central place in the room, she enabled students to have animated conversations.

\section{Advancement of Our Reflective Skills}

A second benefit from doing action research is that teachers have chances to develop their reflective skills. Scholars (Bartlett, 1990; Dewey, 1933; Farrell, 1999, 2004a, 2004b; Greene, 1986; Murphy, 2001; Richards \& Lockhart, 1994; Stanley, 1998; and Zeichner \& Liston, 1996) all point out that reflective teaching includes thoughtful persistent consideration of beliefs or practices, often in relation to the problems teachers face in their teaching. Richards and Lockhart (1994) add that a part of reflective teaching includes "collecting data about teaching, examining their attitudes, beliefs, assumptions, and teaching practices, and using the information obtained as a basis for critical reflection" (p. 1). Greene (1986) adds that reflective teaching also involves intuition, passion, and emotion.

As a part of doing action research, teachers have opportunities to develop their reflection-in-action and reflection-on-action (Schön, 1983, 1987) skills. This is what "reflective practitioners do when they look 
at their work in the moment or in retrospect in order to examine the reasons and beliefs underlying their actions and generate alternative actions for the future" (Stanley, 1998, p. 585). Stanley adds that "such reflective thinking and examination either during or after the fact can lead to greater awareness on classroom teachers' part in relation to their knowledge-in-action, or theories, ideas, metaphors, and images they use as criteria for decision making in their teaching practice" (p. 585).

The reflective nature within the cyclic process of action research can take the teacher beyond classroom interaction to a new awareness of issues at the school and community levels that can affect what happens in the classroom. For example, Ikuko was able to reflect on and gain a renewed awareness of why students could not answer questions in English about something they read. She could more clearly see that the emphasis on preparing students to pass exams, with much more focus on analysis of language rather than on the use of English for communicative purposes, was highly valued by colleagues and administrators in her school. Ikuko also realized that parents in the community understand the importance of teaching English in a way that helps students successfully pass college entrance exams even if they don't agree with it. What Ikuko reflected on reminds me of something Peter Strevens wrote some years ago: "The public is the creator of general levels of expectations, within a community, for the achievement in language of its citizens" (1987, p. 13).

Ikuko further realized through reflection that she cannot go against public expectations and that she needed to creatively work within the established Japanese educational system to give students communicative experience with English while at the same time meeting the expectations of her colleagues, school officials, students' parents, and others who defined how she was expected to teach.

\section{A Forum to Talk about Teaching}

Another benefit of doing action research is the emphasis on creating a forum to talk through issues related to teaching problems, to communicate teaching ideas, and to voice concerns at the classroom, school, and even national levels. During their course experience, Sachiko, Ikuko, and Shelly had chances to attend weekly seminars to talk with other teachers about their own and classmates' action research projects. As Burns (1999) points out, teachers can also create forums for discussion by disseminating their action research projects. For example, it is pos- 
sible to report on action research at conferences (group and individual reports, poster sessions) and in teacher-centered journals.

\section{Limitations of Action Research and Other Avenues to Awareness A Focus on Problems and Best Ways to Solve Them}

There are at least two limitations to action research. First, action research is focused on problems, and when we constantly are looking for ways to understand a problem and ways to solve it, we miss chances to explore teaching ideas outside of this problem (Fanselow, 1987, 1988). For example, Ikuko posed the problem of using considerable Japanese in her class, and she decided to use more English by giving verbal instructions in English to introduce reading activities. She then became aware that many of the students could not fully understand these instructions. As such, she started to look for a better way to give instructions, such as writing key words from her verbal instructions on the board.

Although Ikuko's problem posing process seems reasonable, if there is no focus on a problem and the subsequent search for a best way to solve the problem, Ikuko could be free to see her teaching differently by trying new things simply to see what happens. For example, Ikuko could follow her interest in giving instructions in English, not from a problemsolving point of view by looking for a better way to give instructions, but rather simply to explore what might happen. She could try out a number of ways of giving instructions, such as giving the instructions as a dictation, or as a cloze-dictation (in which students listen, read, and fill in every fifth word), or by having students read instructions on an overhead or handout, or having students listen and translate, or listen to a song with the instructions, or chant them with the teacher, or listen to the teacher whisper the instructions. Again, the idea is that if there is no focus on a problem, the teacher can feel free to explore teaching possibilities simply to see what happens, and this can generate considerable awareness.

\section{A Narrowly Defined Process}

When we consistently follow a single process, we also place limits on how we can explore our teaching and on the kinds of awareness we can gain from our exploration. Action research includes identifying a problem, doing a preliminary investigation, reflecting on what happened, planning an action, implementing the plan, observing the outcome, 
reflecting, planning the next action based on reflection, and moving to the next cycle of re-identifying a problem, and so on. As useful as this process can be, by only following this linear process, we miss chances to gain awareness of our teaching outside of this process.

Although the action research process makes sense and is certainly worth doing, we can go beyond this process by exploring a variety of other avenues to awareness outside the problem-posing one of action research. One of these avenues is to explore simply to see what happens. To do this, Fanselow $(1987,1988,1992 a, 1992 b, 1997)$ suggests we try the opposite of our usual classroom behavior. For example, if we are aware that we say "very good" after most student responses, we can be silent, and then describe what happens. If we usually have students sit in rows, we can have them form a semicircle. If we always teach from the front of the classroom, we can try teaching from the back. If students read aloud in every class, we can ask them to read silently. If we ask students to form groups by themselves, we can assign students to particular groups. And we can do so creatively. For example, we can give out pieces of candy. Students with cherry-flavored candy form a group, lemon another group, and so on. The idea is to discover what we normally do and to try the opposite to see what happens.

Although the three teachers gained awareness from doing their action research projects, they could have gained considerable awareness simply by trying the opposite of their normal practice just to see what would happen. For example, instead of verbally analyzing the grammar of a reading passage, Sachiko could have had students read a passage silently several times while doing a different task each time, such as underlining all past tense verbs, circling subordinate clauses, highlighting main ideas, and answering multiple choice and true-false questions. Likewise, Ikuko could have tried writing down the instructions for students to read one day, then give them orally the next day, then have a student read the instructions aloud to the class the next, continually trying out something different to see what happens.

Another avenue to awareness is exploring to see what is. One way to do this is to explore what we actually do in our teaching as opposed to what we think we are doing. For example, if a teacher thinks she has designed group work activities that keep students talking in English and staying on task, she could tape record students' group work interaction. By doing this, she could analyze the interaction to determine if students are talking in English and staying on task. All three of "our" teachers could have explored what they actually did in relation to what they be- 
lieved they were doing in their classrooms. For example, Sachiko could have asked, "Am I actually teaching students to read as a process of understanding meaning?" Ikuko could have asked, "Do students perceive that I am giving instructions in English so that they will become more competent in comprehending English?" Shelly could have asked, "Am I actually moving off center stage in the classroom when I position myself away from the students?

We can also explore our teaching by considering what we believe as teachers in relation to what we do. Do our beliefs match our actual practices? For example, some teachers who stated that they don't believe in correcting students' oral errors, constantly corrected them anyway (Jimenez-Aries, 1992). Again, all three teachers could have gained awareness by considering their beliefs in relation to what they were doing as teachers. For example, Sachiko could have asked "Does the way I teach reading match my beliefs about teaching reading as a process of comprehending meaning?" Shelly could have asked, "What are my beliefs about teaching students to converse in English? Do I believe that students are genuinely learning to converse in English when I do not participate in conversations with them-when I have them talk in pairs or small groups?"

We can also explore to gain emotional clarity. By exploring our feelings, we can gain awareness about things we feel deeply about, or don't really care about, or are ambivalent about. As Jersild (1955) and Oprandy (1999) emphasize, we can pay attention to the affective side of teaching, including how we feel about the students, teaching, and ourselves as teachers. For example, by focusing on exploring her emotions, Ikuko could have gained more emotional clarity about her inner conflict between teaching students to analyze English to pass exams and teaching them to communicate in English.

\section{Concluding Remarks}

As the three examples given illustrate, action research can provide a way for us to identify problems in our teaching, as well as ways to solve these problems, and this process can provide us with much awareness about our teaching. Action research can expand our reflective skills and provide a lens through which we can discuss teaching issues, problems, and teaching beliefs and practices. However, action research focuses distinctly on problems in our teaching. It also uses a rather narrowly defined linear process, which if followed uncritically can constrict the 
awareness we seek when we undertake action research in the first place. As such, in addition to doing action research, we can benefit from using other avenues to awareness. In addition to problem-solving, we can explore our teaching simply to see what happens, for example, by trying the opposite of what we usually do. We can also explore to see what we actually do as opposed to what we think we do, as well as what we believe in relation to what we do in the classroom. We can also take the exploration avenue of trying to gain emotional clarity about our teaching.

I close with this thought. Exploring our teaching through action research, as well as going beyond this problem-posing and solving process by using other avenues to awareness, can be embodied in the words of Akiko Ueda-Montonaga, who took time to observe her teaching:

I have sought alternatives in teaching and found them. After I found that I have alternatives, I felt freer and securer about deciding on activities for the students... I will continue observing and investigating classroom interaction to find what is going on in my teaching...I will make a wish, make a dream to see teaching clearly and differently, and imagine all the possibilities of teaching! (Gebhard and Ueda-Motonaga, 1992, pp. 190-191)

Jerry G. Gebhard is Professor of English and Director of Graduate Studies in Composition and TESOL at Indiana University of Pennsylvania. He also teaches courses for Teachers College, Columbia University, Tokyo and has had extensive experience teaching in Asia.

\section{Note}

1. To protect the identities of the teachers studying in the MA TESOL program, I use pseudonyms in this report.

\section{References}

Bailey, K. M., Curtis, A., \& Nunan, D. (2001). Pursuing professional development. Boston: Heinle \& Heinle.

Bartlett, L. (1990). Teacher development through reflective teaching. In J. C. Richards \& D. Nunan (Eds.), Second language teacher education (pp. 202214). New York: Cambridge University Press. 
Bellack, A. A., Kliebard, H. M., Hyman, R. T., \& Smith, F. L. (1966). The language of the classroom. New York: Teachers College Press.

Burns, A. (1996). Collaborative action research and curriculum change in the Australian adult migrant English program. TESOL Quarterly, 30(4), 591-598.

Burns, A. (1997). Valuing diversity: Action researching disparate learner groups. TESOL Quarterly, 7(1), 6-11.

Burns, A. (1999). Collaborative action research for English language teachers. Cambridge: Cambridge University Press.

Burns, A., \& Hood, S. (Eds.). (1997). Teachers' voices 2: Teaching disparate learner groups. Sydney, Australia: National Centre for English Language Teaching and Research.

Cornwell, S. (2001). Exploring L1 use in an English discussion class: An action research approach. The PAC Journal, 1(1), 93-108.

Crookes, G. (1993). Action research for second language teachers: Going beyond teacher research. Applied Linguistics, 14(2), 130-144.

Curtis, A. (2001). Hong Kong secondary school teachers' first experiences of action research. The PAC Journal, 1(1), 65-78.

Dewey, J. (1933). How we think. Chicago: Henry Regnery.

Fanselow, J. F. (1977). Beyond Rashomon: Conceptualizing and observing the teaching act. TESOL Quarterly, 11(1), 17-41.

Fanselow, J. F. (1987). Breaking rules: Generating and exploring alternatives in language teaching. White Plains, NY: Longman.

Fanselow, J. F. (1988). "Let's see": Contrasting conversations about teaching. TESOL Quarterly, 22(1), 113-130.

Fanselow, J. F. (1992a). Contrasting conversations. White Plains, NY: Longman.

Fanselow, J. F. (1992b). Try the opposite. Tokyo: Simul Press.

Fanselow, J. F. 1997. Post card realities. In C. P. Casanave \& S. R. Schecter (Eds.), On becoming a language educator (pp. 157-172). Mahwah, NJ: Lawrence Erlbaum.

Farrell, T. S. C. (1999). Reflective practice in an EFL development group. System 27, 157-172.

Farrell, T. S. C. (2001). Exploring teaching in the PAC Journal. The PAC Journal, $1(1), 1-5$.

Farrell, T. S. C. (2004a). Reflective practice in action. Thousand Oaks, CA: Corwin Press.

Farrell, T. S. C. (2004b). Reflecting on classroom communication in Asia. Singapore: Pearson Education.

Gebhard, J. G. (1992). Awareness of teaching: Approaches, benefits, tasks. English Teaching Forum, 30(4), 2-7.

Gebhard, J. G. (1999). Problem posing and solving with action research. In J. G. Gebhard \& R. Oprandy, Language teaching awareness: A guide to exploring beliefs and practices (pp 59-77). New York: Cambridge University Press. 
Gebhard, J. G. (in press). Teaching English as a foreign or second language, (2 $2^{\text {nd }}$ edition.). Ann Arbor, MI: The University of Michigan Press.

Gebhard, J. G., \& Oprandy, R. (1999). Language teaching awareness: A guide to exploring beliefs and practices. New York: Cambridge University Press.

Gebhard, J. G., \& Ueda-Motonaga, A. (1992). The power of observation: "Make a wish, make a dream, imagine all the possibilities!" In D. Nunan (Ed.), Collaborative language learning and teaching (pp. 179-191). Cambridge: Cambridge University Press.

Greene, M. (1986). Reflection and passion in teaching. Journal of Curriculum and Supervision, 2, 68-81.

Jersild, A. T. (1955). When teachers face themselves. New York: Teachers College Press.

Jimenez-Aries, I. (1992). A descriptive study of error treatment in ESL settings. Unpublished MA thesis, Indiana University of Pennsylvania.

Kemmis, S., \& McTaggart, R. (1982). The action research planner. Victoria, Australia: Deakin University Press.

Murphy, J. M. (2001). Reflective teaching in ELT. In M. Celce-Murcia (Ed.), Teaching English as a second or foreign language, $3^{\text {rd }}$ edition (pp. 499-514). Boston: Heinle \& Heinle.

Oprandy, R. (1999). Making personal connections to teaching. In J. G. Gebhard \& R. Oprandy, Language teaching awareness: A guide to exploring beliefs and practices (pp. 122-146). New York: Cambridge University Press.

Richards, J. C., \& Farrell, T. S. C. (2005). Professional development for language teachers. New York: Cambridge University Press.

Richards, J. C., \& Lockhart, C. (1994). Reflective teaching in second language classrooms. New York: Cambridge University Press.

Schön, D. A. (1983). The reflective practitioner: How professionals think in action. New York: Basic Books.

Schön, D.A. (1987). Educating the reflective practitioner. San Francisco: JosseyBass.

Sitler, H. C. \& Tezel, Z. (1999). Two action research projects. In J.G. Gebhard \& R. Oprandy, Language teaching awareness: A guide to exploring beliefs and practices (pp. 195-210). New York: Cambridge University Press.

Stanley, C. (1998). A framework for teacher reflectivity. TESOL Quarterly, 32(3), 584-591.

Stewart, T. (2001). The value of action research in exploring methodology: A case of instruction on questioning in debate. The PAC Journal, 1(1), 79-92.

Strevens, P. D. (1987). The nature of language teaching. In M. H. Long \& Jack C. Richards (Eds.), Methodology in TESOL (pp. 10-25). New York: Newbury House.

Thorne, C., \& Wang, Q. (1996). Action research in language teacher education. ELT Journal, 50(3), 254-262. 
van Lier, L. (1993). Action research. Paper presented at the PeruTESOL conference.

Wallace, M. J. (1998). Action research for language teachers. Cambridge: Cambridge University Press.

Zeichner, K. M., \& Liston, D. P. (1996). Reflective teaching: An introduction. Mahwah, NJ: Lawrence Erlbaum.

(Received July 12, 2004; accepted December 1, 2004) 
